\title{
Agents and Mechanisms of Terrorist Campaigns
}

A contribution to a general theory of rationality

\section{Domenico Tosini}

\section{OpenEdition}

\section{Journals}

Electronic version

URL: http://journals.openedition.org/ress/973

DOI: $10.4000 /$ ress.973

ISSN: $1663-4446$

\section{Publisher}

Librairie Droz

\section{Printed version}

Date of publication: 15 December 2011

Number of pages: $43-70$

ISBN: 978-2-600-01575-2

ISSN: 0048-8046

\section{Electronic reference}

Domenico Tosini, «Agents and Mechanisms of Terrorist Campaigns », Revue européenne des sciences sociales [Online], 49-2 | 2011, Online since 01 January 2015, connection on 19 April 2019. URL : http:// journals.openedition.org/ress/973; DOI : 10.4000/ress.973 


\title{
AGENTS AND MECHANISMS \\ OF TERRORIST CAMPAIGNS
}

A CONTRIBUTION TO A GENERAL THEORY OF RATIONALITY

DOMENICO TOSINI

University of Trento

domenico.tosini@unitn.it

\begin{abstract}
The paper offers a framework to identify the most important generative processes of terrorist campaigns. It focuses on links between macro and micro levels involving a plurality of agents, the most important being armed groups, insurgency collaborators, and active fighters, and, at the same time, three kinds of causal or social mechanisms. These are: situational mechanisms that identify agents' constraints and opportunities associated with the psychological, cultural, political, economic, and military context of an armed struggle; action formation mechanisms, that analytically concentrate on agents' decision-making; and transformational mechanisms, describing the interactions between agents. Armed groups instrumentally resort to terrorist tactics to purse operative goals associated with asymmetric conflicts, but in the case of collaborators and active fighters the article proposes moving beyond assumptions of the rational choice theory and adopting a more general paradigm of rationality.
\end{abstract}

Keywords: Al-Qaeda, axiological rationality, rational choice theory, social mechanism, suicide mission, terrorism

Résumé. L'article offre un aperçu théorique des plus importants processus qui engendrent les campagnes terroristes. II se concentre sur les rapports entre les niveaux macro et micro concernant une pluralité d'agents, les plus importants étant les groupes armés, leurs collaborateurs et leurs combattants et, en même temps, trois types de mécanismes causaux ou sociaux. Ces derniers sont: les mécanismes situationnels, qui identifient les contraintes et les opportunités des agents et qui sont associés au contexte d'une lutte armée; les mécanismes de formation de l'action, qui se concentrent sur le processus décisionnel des agents; et les mécanismes de transformation, qui décrivent les interactions entre les agents. Les groupes armés recourent de façon instrumentale à des tactiques terroristes pour des fins liées aux conflits asymétriques. Dans le cas des collaborateurs et des militants, l'article juge nécessaire d'aller au-delà des postulats de la théorie du choix rationnel et d'adopter un paradigme plus général de la rationalité.

Mots-clés: Al-Qaeda, rationalité axiologique, théorie du choix rationnel, mécanisme social, mission suicide, terrorisme 


\section{INTRODUCTION}

The paper offers a framework to identify the most important generative processes of terrorist campaigns'. It argues for more comprehensive explanations than those based on macro-causal analyses. This requires focusing on links between macro and micro levels involving a plurality of agents. Campaigns are generally contingent on three main agents: elite members of armed groups (AGs) who plan them; insurgency collaborators (ICs) emerging from those communities whose interests AGs claim to defend; and active fighters (AFs) who carry out terrorist attacks and who emerge from the same communities². At the same time, the analysis of these agents has to be combined with three kinds of causal or social mechanisms, referring to the most important conditions, motivations, and social interactions underlying a terrorist campaign ${ }^{3}$. First, there are situational mechanisms that identify agents' constraints and opportunities associated with the psychological, cultural, political, economic, and military context of an armed struggle. They specify the space of possibilities within which agents select their lines of actions. Second, such mechanisms are linked to action formation mechanisms that analytically concentrate on agents' decision-making. Their clarification helps specify the most basic or "molecular" micro-foundation processes conducive to violence. Finally, both mechanisms are intertwined with transformational mechanisms, describing the interactions of agents and bringing about a terrorist campaign as the originally observed collective and macro-outcome. Figure I, which is inspired by J. Coleman (1990), serves as a roadmap for our investigation:

I Empirically, terrorist campaigns are macro outcomes consisting of sequences of deliberate attacks against civilians or non-combatants (Tosini, 2007a, 2007b; cf. Cassese, 2006; Goodwin, 2006).

2 In this sense, the communities from which ICs and AFs emerge constitute the social environment of a terrorist campaign.

3 For the notion of social mechanism referred to here, see Hedström and Swedberg (1998), Barbera (2004), Cherkaoui (2005), Hedström (2005), Elster (2007), Hedström and Yliloski (2010) and Manzo (2010). 
Figure I : Agents and Generative Mechanisms of Terrorist Campaigns

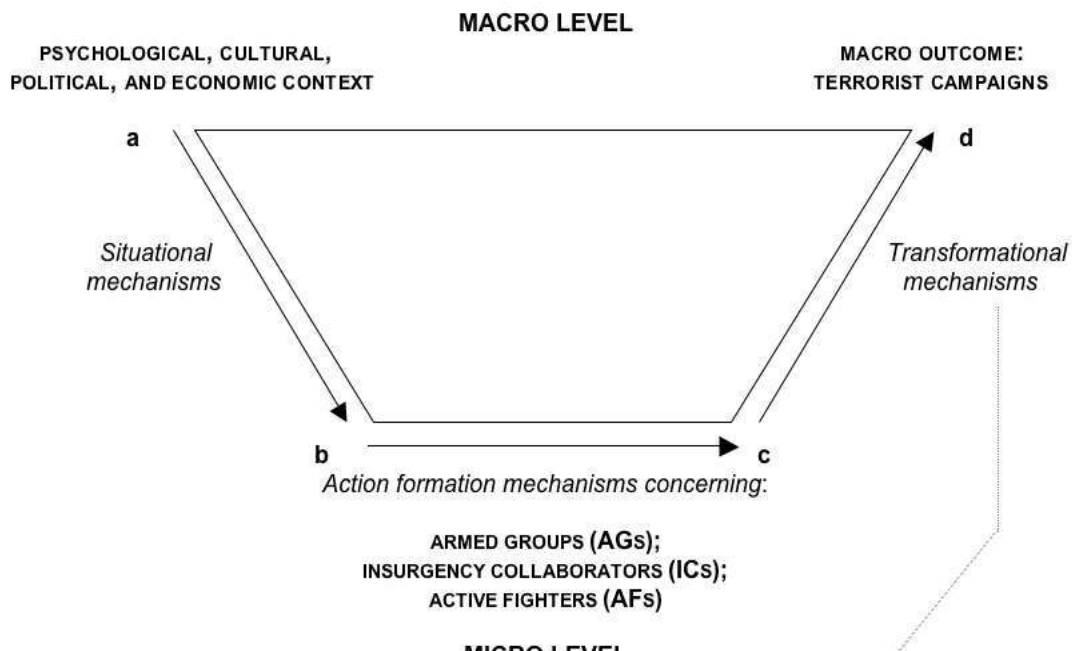

MICRO LEVEL

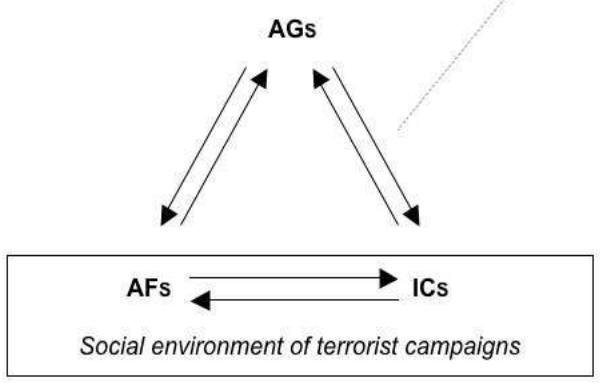

The three agents are analyzed as follows: AGs in Section 2, ICs in Section 3, and AFs in Section 4. The three social mechanisms are simultaneously and separately discussed for each agent within the corresponding section ${ }^{4}$. Given the enormous variety of terrorist campaigns, this paper does not pretend to be an

4 However, the concatenations $\mathrm{a} \rightarrow \mathrm{b} \rightarrow \mathrm{c} \rightarrow \mathrm{d}$ concerning the three agents are inevitably intertwined. For each agent, the other agents are part of conditions influencing his action 
exhaustive contribution, but only an ideal-typical (in Weber's parlance) generative model. Empirical evidence, for the most part drawn from Al-Qaeda's armed struggle, should be considered only as illustrative examples and not immediately intended as claims of the primary, let alone unique, causal role of examined factors. Special attention is paid to the multi-faceted constellation of motivations behind agents involved in terrorism, arguing for a more general paradigm of rationality beyond certain assumptions of the rational choice theory $y^{5}$.

\section{ARMED GROUPS}

\section{I. CONTEXT OF TERRORIST CAMPAIGNS}

Here, we conventionally limit our analysis to non-state AGs. A concise typology of terrorist campaigns might be based on the following six recurrent political outcomes or strategic objectives (Tosini, 2007a, 2007b; cf. Schmid and Jongman, 1988; Hoffman, 2006; Law 2009): I) the liberation of a territory associated with a specific ethnic and/or religious community (nationalist campaign), e.g., the Basque ETA vs. the Spanish government and the Palestinians vs. Israel; 2) the liberation of a territory encompassing several communities and their political entities, as well as their unification based on common ethnic and/or religious traits (pan-nationalist campaign), e.g., the transnational jihadist movement from the I980s anti-Soviet resistance in Afghanistan up to the recent jihadist groups' struggle embracing the entire Muslim community or nation (ummah); 3) the overthrow of existing regimes to establish alternative orders (revolutionary campaign), e.g., the Red Brigades' struggle for a communist society in Italy; 4) the defense or re-establishment of a dominant position (vigilant

formation. Each agent's decision-making takes into account the other agents' possible and effective decisions. Each concatenation $\mathrm{a} \rightarrow \mathrm{b} \rightarrow \mathrm{c} \rightarrow \mathrm{d}$ should also be conceived of as a recursive process. This means that the interactions and the mutual influence $(c \rightarrow d)$ between agents associated with their action formation $(b \rightarrow c)$ tend to impact on the original space of possibility of each agent by producing a new structure of situational mechanisms ( $\left.a^{\prime} \rightarrow b^{\prime}\right)$. This might be followed by further cycles of the same kind, whose cumulative effect bring about the final output consisting of a terrorist campaign (see Coleman 1990; Manzo 2009).

5 Here we refer mainly to the general theory of rationality elaborated by R. Boudon (2003, 2007, 2009a, 2009b; 2010; see also Cherkaoui, 2007). 
campaign), e.g., the Ulster paramilitary groups vs. the Republicans in Northern Ireland; 5) the fighting to support forces of good involved in a cosmic war against those of evil (symbolic campaign), e.g., the Japanese cult of Aum Shinrikyo, known for the 1995 sarin gas attack on the Tokyo subway; 6) the achievement of very specific goals such as the stop of abortion (single-issue campaign), e.g., the Army of God's violence following the 1973 legalization of abortion in the US.

Certain campaigns are a combination of types. Our case study, Al-Qaeda and its network of extremist Islamists, is a clear example. Nationalist objectives can be attributed to Al-Qaeda's affiliates, such as some Iraqi Sunni insurgents, and allies, such as the Taliban in Afghanistan, with their goals to compel occupiers to withdraw from Iraq and Afghanistan (Hashim, 2006, 2009; Pape, 2005; Hafez, 2007; Pape and Feldaman, 2010). However, a more distinctive feature of Al-Qaeda and other affiliates such as Al-Qaeda in Iraq is a pan-Islamic nationalism, namely a resistance by a "vanguard" of Muslim fighters (Campanini and Merzan, 2007) in defense of the Muslim community and for the liberation of all its territories from "un-Islamic" forces such as the US and its allies, the "far enemy" (al-adou al-baeed) (Al-Zawahiri, 200I; Al-Zayyat, 2004; Gerges, 2005; Hegghammer, 20ıо; Kepel and Milelli, 2008; Moghadam, 2008; Riedel, 2008; Gunaratna and Oreg, 20I0). Furthermore, these objectives are intertwined with the revolutionary attempt to overthrow "apostate" regimes in the Muslim world, the "near enemy" (al-adou al-qareeb). Several Sunni groups affiliated or allied with Al-Qaeda pursue the destruction of "infidel" authorities ruling their countries: the Al-Qaeda in the Islamic Maghreb in Algeria; Al-Qaeda in the Arabic Peninsula in Saudi Arabia; Jemaah Islamiyya in Indonesia; Lashkar-e-Jhangvi in Pakistan; and the Al-Shabab Al-Majahedeen in Somalia. Finally, an additional feature of certain Sunni campaigns, such as those of Al-Qaeda in Iraq and some Pakistani organizations, has been sectarian attacks on the Shiites, a form of vigilantism (Nasr, 2006; Cordesman, 2008; Tosini, 2010).

Strategic objectives and the underlying grievances and cleavages certainly help understand general conditions of an armed struggle, but are insufficient to account for AGs' decision to employ terrorism instead of other combat methods. This requires focusing on more specific constraints or situational mechanisms affecting AGs' actions and related to the operational context of terrorist 
campaigns. From this perspective, the asymmetric nature of conflicts is a crucial factor (Boyns and Ballard, 2004). Campaigns such as those of Al-Qaeda and the Taliban, for example, consist of confronting unrivalled superpowers like the US army. Here, AGs bypass direct fighting with the enemy and take advantage of its weaknesses to restore a balance of coercion (Kushner, 2003; Thornton, 2007). Achieving strategic objectives necessitates realizing intermediate effects that we call process or operative goals (cf. Abrahms, 2012), which include the capacity for combat methods exerting coercion under constraints of asymmetry. A question remains: what is the rationality of terrorism with respect to such circumstances?

\subsection{RATIONALITY OF TERRORIST TACTICS}

To answer, we focus on the action formation mechanisms of AGs, who should be analyzed as rational agents resorting to tactics to deal with an imbalance of power (Crenshaw, 1998; US Army-Marine Corps, 2007). Al-Qaeda's operational art, for example, conceives of all means as legitimate combat methods, including mass casualty attacks on civilians (Adamsky, 20 о). For jihadists, rules of international law exist only for their enemies. Terrorists exploit this kind of asymmetry to their advantage (Münkler, 2005; Kaldor, 2006; Thornton, 2007; Reed, 2008). Iraqi terrorism and incidents such as the 2004 Madrid and 2005 London bombings clearly exemplify this stance. Since 2003 an increasing wave of car bombs in Iraq have targeted civilians, particularly the Shiites. Searching for tactical alternatives to direct confrontations with the US army, AGs have aimed to compensate for their military weakness and to exert pressure on occupiers and their local allies (Hafez, 2007). As with all terrorist tactics (Schmid and Jongman, 1988), Iraqi AGs have played on the fear and shock among civilians to influence audiences beyond their direct targets (i.e., their victims) by: I) creating a condition of chaos and insecurity among the Iraqi population to delegitimize incumbents and the new Iraqi government; 2) terrorizing civilians to deter Iraqis viewed as effective or potential collaborationists, especially (even if not exclusively) the Shiites, from any compliance with occupiers; 3) provoking counterinsurgent and Shiite militia reprisals against the Sunni community to polarize sectarian conflicts between Sunni Arabs and Shiite Arabs (Nasr, 2006; Cordesman, 2008; Tosini, 20ı0). 
More in-depth analyses should then explain the calculations behind specific terrorist tactics such as suicide bombings. This requires considering peculiar advantages of kamikaze attacks. "Technical” potentials are often stressed in the literature: I) greater damage with fewer combatants and casualties; 2) the ability of disguised bombers to enter heavily guarded locations; 3) their capacity to modify direction to maximize casualties; 4) the impossibility, for the enemy, of obtaining information from successful attackers; 5) and the minimal costs of attacker training (Gambetta, 2005; Pedahzur, 2005; Pape, 2005; Ayers, 2008; Moghadam, 2008; Hassan, 2010). These features make a difference when destroying hard targets like military barracks and armored vehicles. But the question is why certain AGs, for example in Iraq, have adopted suicide bombings against soft targets like the Shiite population, when other tactics could also massacre defenseless civilians without sacrificing militants as bombers (Cordesman, 2008).

To answer, certain communicative advantages of suicide attacks should be examined (Hoffman and McCormick, 2004). Following signaling theory (Gambetta, 2009a, 2009b), our hypothesis is that AGs rationally rely on the expected ability of suicide missions to work as effective signals of determination and of a potential of violence behind the AGs' demands and threats. AGs probably count on the discriminating features of immolation. Sacrificing one's life is a costly action and a tangible and hard-to-fake signal, which makes it a convincing proof of commitment and fanaticism. Such aspects is exploited by AGs for propaganda purposes by using bombers' last wills circulating on the Internet. Here, representations of attackers and manipulations of their images capitalize on the signaling qualities of "martyrdom". Videos and other accounts, while obsessively emphasizing the extraordinary nature of such actions, aim at merging AGs' and bombers' identities in order to credibly convey the military preparation, extreme devotion to a good cause, radical opposition to the enemy, and unquestionable willingness to die behind the entire organization ${ }^{6}$.

6 This has also to do with the fact that AGs strive to expose their enemy's vulnerability and inability to exert deterrence. As stated by H. Popitz, "the attacker and the martyr publicly put into question the completeness [or fullness] of power [Vollkommenheit der Marcht]." (Popitz, 1992: p. 60; see also Poggi, 200I). Needless to say, from this standpoint the major challenge to the completeness of power is the fusion of the attacker and the martyr (i.e., the suicide bomber). 


\subsection{INTERACTIONS WITH COLLABORATORS AND FIGHTERS}

Turning to transformational mechanisms, we first focus on AGs' main lines of action towards the other agents of our model. Consider once again the case of suicide bombings. AGs rationally engage in suicide attacks to psychologically constrain not only the enemy but also at least two other audiences or receivers, namely potential ICs and potential AFs within the community. AGs clearly strive for the community's support. To gain collaboration, videos and biographical accounts of bombers frequently exalt the latter's nobility, zeal, and devotion to religion. AGs want their presumed constituency to be confident of militants' determination? This plays once again on the distinctive signaling qualities embodied in the costly behavior of suicide missions. As with communication directed towards the enemy, AGs exploit suicidal acts to prove extreme self-sacrifice for their constituency's interests, gambling on bombers' ability to succeed as a tangible, hard-to-fake signal of solidarity ${ }^{8}$. Following the same logic, kamikaze communiqués are meant as a recruitment tool for new AFs. Here, missions are systematically framed as martyrdom in the service of a good cause and a god. More or less explicit calls are made for all Muslims' highest moral obligation: sacrificing oneself in battle for jihad against oppressors of the Muslim nation?.

7 In last wills circulating on the Internet, fighters' reputations are frequently underlined as a form of "authority" by leading figures like the Al-Qaeda's commanders. An example is a video in which Ayman Al-Zawahiri emphasizes the moral and religious integrity and the heroism of Shehzad Tanweer and the other members of the 2005 London suicide commando (As-Sahab, 2006). In pioneering the use of suicide bombings, organizations such as Hezbollah and Hamas have been keenly aware of the propagandistic relevance of celebrating their fallen. On the website of AI-Qassam (20I0), Hamas's military wing, an entire section continues to be dedicated to its "martyrs". On the Iraqi battlefield, too, insurgents have produced memories of their fighters, as documented by the long series of Al-Furgan's (2009) productions, titled The Knights of Martyrdom, in a clear attempt to mark the courage, greatness, and devotion of AI-Qaeda's militants (ICG, 2006).

8 Generating this understanding is also instrumental to winning the community's support in competition with other AGs (Bloom, 2005; Pedahzur, 2005).

9 An example is a 2006 clip titled The Convoy of Martyrs, released by Al-Qaeda's Mujahideen Shura Council, in which the following statement is made by a Saudi militant: "Anyone who loves Allah should follow this path. I ask my mother and father to be patient. Let them know that their son is in the land of jihad, whether he leaves or dies, he will always be there, living, both now and in the hereafter. We shall meet in paradise. Allah is more merciful than both of you, my dear parents. Allah has called me and He shall protect me and make me achieve 
Emphasis is often put on the suggestive appeal to pride and manhood signaled by the fallen in defense of their "brothers" and, conversely, on the sense of shame and guilt that should be felt by those remaining passive once confronted with abuses and violence against their community (Hafez, 2006).

Attempts by AGs to gain support from the community members include other lines of action. First of all, some AGs provide services during their campaigns, e.g., Hezbollah's and Hamas's economic aid for AFs' families, especially those of suicide bombers (Levitt, 2006). Second, symbolic recognitions are used to mark the elevated status of community members paying a high price, the loss of a beloved, in the armed struggle. Finally, physical and psychological coercion can also be a mechanism to force compliance and recruitment. Selective violence against civilians is often employed both to punish collaboration with the enemy and to deter defections (Kalyvas, 2006). In Iraq, for example, in addition to attacks on the Shiites, insurgents have targeted even Sunnis, especially those who since 2006 have established the Al-Sahawa movement forming an alliance with Americans to oppose Al-Qaeda in Iraq's interference in tribes' economic and political interests (Cordesman, 2008).

\section{INSURGENCY COLLABORATORS}

\section{I. CONDITIONS OF COLLABORATION}

Beside the pressure of the AGs, collaboration is also contingent on political, economic, and cultural conditions affecting ICs. Political processes causing discrimination and deprivation can certainly drive the community members to assist AGs. In 2003 in Iraq, for example, two orders of the Coalition Provisional Authority - aimed at the "de-Baathification" of Iraq and the dissolution of the former Iraqi army - marked the Sunni Arabs' traumatic exclusion from the new regime in addition to the occupiers' interference in

martyrdom. And, O' my brother Hassam, Allahu Akhbar, O' Hassam. I hope you are listening to me right now. I beg you to depart to the land of honor and manhood. Don't just sit there and stay behind, and don't listen to anyone who tries to stop you. Just go and kill the Americans. Just kill them and don't leave any survivors." (Golbalterroraltert, 2007). 
their tribal interests. Indeed, the US gave unprecedented power to the Shiite Arabs and the Kurds, increasing the Sunnis' humiliation and adding the risk of reprisals by their Iraqi rivals (Hashim, 2006; 2009).

Political and religious ideologies can also facilitate support. For example, Islamist narratives of jihad and martyrdom have been a vital source of legitimacy for several AGs in recent decades, e.g., Hezbollah, the Palestinian organizations, and the Al-Qaeda network. This results from two main trends. The first goes back to the Sunnis' radical conception of jihad inspired by such thinkers as Taqi Al-Din Ahmad Ibn Taymiyya (d. I328), Muhammad Ibn Abd Al-Wahhab (d. I79I), and Sayyid Qutb (d. 1966). The second refers to the Shiite tradition. After the centuries of quietism that followed the Imam Husayn's martyrdom (680 AD), since the I960s several clerics such as Rudollah Khomeyni (d. 1989), Muhammad Baqir Al-Sadr (d. 1980), and Muhammad Husayn Fadlallah (b. 1935) have called for Muslims' armed militancy, including suicide missions: a crucial rationale for both the young Iranian "martyrs" of the I980s Iran-Iraq war and for the Hezbollah campaign against Israel in the I980s and I990s. Despite the differences between the two traditions a convergence has emerged in the last two decades, also due Hezbollah's influence on Hamas's use of suicide missions since the I990s (Freamon, 2003; Cook 2005; Moghadam, 2007; on martyrdom in Islam see also Denaro, 2006; Cook, 2007). Iraq, too, has experienced a revival of Islamism since the First Gulf War (I99I), when Saddam Hussein began to concede more space to religious institutions, thus creating a context from which post-2003 Sunni insurgents could draw on ideological resources to gain legitimacy (Jackson, 2006).

\subsection{ACTION FORMATION MECHANISMS OF SUPPORT}

Rooted in such conditions, collaboration can be instrumentally inspired by several advantages: the efficacy attributed to armed struggle (propagandized as such by AGs) in defending interests, such as the Sunni Arabs' privileges endangered by the fall of Saddam Hussein; and a variety of incentives offered by some AGs, including economic assistance to AFs' families. Consider the first circumstance. Escalations of suicide bombings in Iraq since 2003, for instance, were related to 
turning points when Sunnis supported insurgency in order to resist challenges to their power: I) the increase in attacks in the second half of 2003 followed the 2003 coalition orders' dismantling of their rule; 2) the high number of attacks between May and July 2004 was in reaction to the US handover of authority to the interim government; 3) a further escalation between September 2004 and January 2005 was due to the election of the assembly tasked with drafting the new constitution; 4) a new massive wave between April and September 2005 was triggered by the appointment of Kurdish leader Jalal Talabani as president and the Shiite Ibrahim Jaafari as prime minister, and by their endorsement of the draft constitution; 5) a new increase in the second half of 2006 was a response to the assassination of Al-Qaeda in Iraq's leader, Abu Musab Al-Zarqawi, and to the subsequent security plan of the new Prime Minister Nuri Al-Maliki (which included an amnesty for insurgents); 6) a final escalation between January and September 2007 was in reaction to the US troop "surge" (Hafez, 2007; Tosini, 2010).

Attempts to explain collaboration exclusively in terms of benefits are nonetheless questionable because of some limitations of accounts inspired by the rational choice theory. As shown by R. Boudon (2003, 2005, 2007, 2009a, 2009b), the strongest versions of the rational choice theory include six postulates: any social phenomenon emerges from individual decisions (individualism: postulate $\mathrm{PI}_{\mathrm{I}}$ ); actions can always be understood (understanding: P2); actions are caused by reasons in the minds of agents (rationality: $\mathrm{P}_{3}$ ); these reasons stem from consideration by agents of the consequences of their behavior (instrumentalism: $\mathrm{P}_{4}$ ); agents focus mainly on the consequences to themselves (egoism: $\mathrm{P}_{5}$ ); agents choose actions with the most favorable balance of costs and benefits (maximization: P6).

Further versions have certainly amended these assumptions. Among them, the theory of bounded rationality replaces P6 with the hypothesis P6' that agents have limited capacity to maximize. In this sense, terrorism generally fails to achieve AGs' strategic goals (Abrahms, 20I2). Nonetheless, AGs and some ICs resort to violence for more limited operative objectives associated with the asymmetry of warfare and to satisfy short-term interests. Apart from material benefits, social prestige and reputation conferred by AGs' leaders on ICs have desirable symbolic advantages, namely a "social capital" exerting influence 
within one's ethnic or religious circle. Likewise, postulate $\mathrm{P}_{5}$ may be complemented with the claim $\mathrm{P}_{5}$ ' that, in some cases, ICs act not egoistically but also for their intimates or for their community.

Two further perspectives should be considered. The first concerns the impact of affective factors on ICs' actions (Weber, 1978 [1922]). For example, support for AGs can be explained by a desire for revenge due to emotions such as outrage at the enemy's violence and abuses. Second, no less crucial factors are norms and values held unconditionally (i.e., regardless of consequences of actions). This orientation can be better conceptualized within a general theory of rationality, in which the versions of the rational choice theory mentioned above are only specific forms ${ }^{10}$. Other forms of rationality are possible and require exclusively $\mathrm{P}_{1}, \mathrm{P}_{2}$, and $\mathrm{P}_{3}$. Here, agents' orientation is still rational but not reducible to instrumentalism, which means that at times even $\mathrm{P}_{4}$ is untenable. On this level of rationality both descriptive and normative beliefs are possible, which correspond to the forms of cognitive rationality ${ }^{11}$ and axiological rationality ${ }^{12}$, respectively. Several accounts of ICs' actions referring to ideological and religious principles are clearly examples of the axiological orientation ${ }^{13}$. Their reduction to the instrumental versions of rationality would be a crude error.

I0 A general theory of rationality "assumes that any collective phenomenon is the effect of human individual actions and that the action of an observed actor is always understandable, provided the observer has sufficient information, and finally that the causes of the actor's action are the reasons he has to undertake it" (Boudon, 2009a, p. 186).

II The notion of cognitive rationality can be formalized as follows: "Given a system of arguments $\{S\} \rightarrow P$ explaining a given phenomenon $\mathrm{P}$, it is cognitively rational to accept $\{\mathrm{S}\}$ as a valid explanation of $P$ if all the components of $\{S\}$ are acceptable e mutually compatible and if no alternative explanation $\{S\}^{\prime}$ is available and preferable to $\{S\}^{\prime \prime}$ (Boudon 2009a, p. I89).

12 Also termed value rationality (Wertrationalität) in Weber's parlance (1978 [1922]). The notion of axiological rationality can be formalized as follows: "Given a system of arguments $\{\mathrm{Q}\} \rightarrow \mathrm{N}$ containing at least one axiological statement and concluding that the norm $\mathrm{N}$ is valid, all the components of $\{Q\}$ being acceptable and mutually compatible, it is axiologically rational to accept $N$ if no alternative system of arguments $\{Q\}$ ' preferable to $\{Q\}$ and leading to prefer N' to $N$ is available" (Boudon, 2009a: 190; see also Boudon, 2003, 2005, 2007, 2009b; Cherkaoui, 2007; Brym and Hamlin, 2009).

13 Much anecdotical evidence documents a firm adhesion to specific beliefs having an absolute validity. For example, a Palestinian woman interviewed in 2005 explained her reasons supporting as follows the suicide missions of her three sons: "Believe me, when it comes to my 


\subsection{DYNAMIC OF COLLABORATION}

A second component of transformational mechanisms responsible for terrorist campaigns relates to ICs' lines of action towards both AGs and potential AFs. Collaboration with AGs takes on several empirical forms. It offers important resources for AGs such as information, hideouts, and territory for military training. After the 2003 fall of the Baath regime, for instance, the occupiers' interference in Sunni tribes' interests induced their leaders to form an alliance with both former Baathists and even extremist Islamists, including Al-Qaeda in Iraq. This explains why insurgents were able to maintain strongholds inside Sunnidominated areas, like the Anbar province, from where they could launch attacks on Baghdad and on traditional Shiite holy cities such as Karbala and Najaf.

On the other hand, the Iraqi Sunnis demonstrate rationality as well with their decisions to switch sides once conditions for their collaboration with insurgents turn unfavorable. As seen, in 2006 Sunni tribal leaders established their own militias, known as Al-Sahawa, to defend their interests against Al-Qaeda's fanaticism. They had become increasingly alienated from their former ally and supportive of American counterinsurgency, which played on such opposition by financing and arming the militias (Galbraith, 2008; Gonzalez, 2009; Hashim 2009; Munson, 2009). In the long run, the US military superiority and economic aid to Al-Sahawa made Al-Qaeda's reprisals incapable of preventing further Sunni defections.

Moreover, everyday life in communities supporting AGs includes cultural emblems and rituals exalting militancy and martyrdom. Analytically, this has to do with those ICs' lines of actions involving potential AFs and facilitating the latter's engagement and recruitment. Radical religious centers and their leaders are a case in point. Mass media, too, are important agents

sons, I am one of the most compassionate mothers. But this [of martyrdom] is a sacred duty, which no emotion whatsoever can supersede [...]. We cannot stop sacrificing just because we feel pain. What is the meaning of sacrifice? One sacrifices what is precious, not what is of little value. My children are the most precious thing in my life. That is why I sacrificed them for a greater cause - for God, who is more precious than them. My son is not more precious than his God, he is not more precious than the places holy to Islam, and he is not more precious than his homeland or his Islam. Not at all. [...]. But he is not throwing himself to death or to perdition. This is not death. This is not called death. It is called martyrdom." (MEMRI, 2005). 
influencing potential AFs by emphasizing militants' heroism. Under certain circumstances, almost an entire community can overwhelmingly identify itself with the political cause and ideology encouraging the armed struggle and martyrdom. Both moral disengagement with respect to violence and the de-humanization of the enemy (in the sense of Bandura, 1998) might strongly penetrate a community enough to normalize its perception of terrorism, as shown by ethnographic investigations of Palestinians ${ }^{14}$.

\section{ACTIVE FIGHTERS}

\section{I.PROFILES, PERSONALITY, AND IDEOLOGICAL FRAMINGS}

The first set of situational mechanisms responsible for terrorist militancy concerns the socio-demographic background of AFs. Radicalization depends to some extent on conditions related to national and ethnic belonging, religious affiliation, education, and marital and economic status. Today, their explanatory relevance is continuously discussed, especially in comparative analyses of extremist Islamists. Apart from the much-studied Palestinians, recent research has focused on fighters involved in the Iraq insurgency, particularly on foreign jihadists from Muslim countries (Hafez, 2007; Cordesman, 2008; Moghadam, 2008; Hassan, 20I0; Pape and Feldman, 20I0). One example is a report on nearly 700 records (aka Sinjar Records) of militants that entered Iraq between August 2006 and August 2007 (CTC 2007, 2008). Their average age was 24-25, which suggests that most of them were first-time fighters rather than veterans of previous campaigns

I4 As stated by A. M. Oliver and P. Steinberg, "Support for suicide bombings went far beyond the military wing of the nationalist and Islamist movements. Parents dressed their babies and toddlers as suicide bombers and had them photographed in local photography studios. Children marched with suicide belts around their chests. University exhibitions included one that recreated an actual suicide bombings carried out in the Sbarro restaurant in Jerusalem, replete with pizza slices and bloody body parts. The Palestinians Authority named popular soccer tournaments after martyrs belonging both to Fatah and the rival Hamas, with even suicide bomber who blew himself up during an Israeli family's celebration of Passover, killing thirty of them, thus honored. On public TV, the Palestinian Broadcasting Corporation aired videos of men being lured away by the hur, the beautiful virgins of Paradise promised to martyrs, as if they were commercials or public service announcements. If the term cult did not suggest a fringe phenomenon, we might begin to speak of a cult of martyrdom." (Oliver and Steinberg, 2005: p.xxiii). 
like the Afghan anti-Soviet jihad. Of the 156 fighters that specified their occupation, $42 \%$ were students. Twenty-one countries were mentioned as their origin. Saudis contributed the highest number of fighters (4I \% of the 576 that listed their nationality). The other most common countries were Libya, Morocco, Syria, Yemen, and Algeria. Two were also from France, one from Britain, and one from Sweden. Libya contributed the most fighters per capita. Of the 376 fighters that indicated their "work" in Iraq, $56 \%$ were to be suicide bombers (istishhadi) and the plurality of them were Saudi (7o fighters or $47 \%$ of the total of Saudi fighters). Nonetheless, Libyans ( $5 \mathrm{I}$ or $85 \%$ of the total of Libyan fighters) and Moroccans (22 or 91 \% of the total of Moroccan fighters) who refer to their "work" were much more likely to be enlisted as bombers. Focusing on Saudis, another report shows the high presence of northerners, which can be attributed to the fact that both geographic proximity to Iraq and loyalties to tribes located on both sides of the border might have conditioned recruitment (Hegghammer, 2007).

Second, personality traits should also be examined as situational factors. Many scholars tend to marginalize their significance, underlining the primary role of political and ideological causes ${ }^{15}$. But this does not explain why only a minority of people exposed to such conditions radicalize and become AFs. For instance, a recent study comparing a group of 15 incarcerated Palestinian would-be suicide bombers with a control group of 12 non-suicide terrorists reveals that would-be suicide attackers, if not psychotic, had distinctive psychological traits. They manifested two main personality patterns - a dependent-avoidant personality ( $60 \%$ of the would-be suicides as opposed to the I7 \% of the controls) and an impulsive-unstable personality $(26.7 \%$; $67 \%$ in the control group) - and suicidal tendencies (40\%; with no symptoms in the control group) (Merari, 2oro). These features constitute factors that make individuals more amenable to recruiting for suicide missions ${ }^{16}$.

15 "The currently prevailing opinion among terrorism researchers is that suicide terrorists are normal and that they do not have any distinctive psychological features. This opinion, however, stems from absence of evidence to the contrary, rather than from a direct investigation of suicide bombers". (Merari, 2010, p. 268).

16 First of all, "dependent-avoidant individuals are more susceptible to external influence, more willing to please, less likely to refuse requests by persons of authority, and are thus more 
Third, ideological narratives circulating in the community and propagandized by AGs also play a role. This has to do with the strength of certain convictions leading to militancy and participation in highly risky missions. For example, political and religious values seem to be determinant for some foreign militants who volunteered for the Iraqi insurgency. Field research and interviews document the devotion of young Saudis to the defense of the Islamic community. This derives from a specific ideology which can be traced back to the 1960s, when King Faisal propagandized the ideal of Islamic solidarity (al-tadamun al-islami), forming the basis of the pan-Islamic nationalism previously discussed. In the 1980s the Saudi state played on this ideal to mobilize jihadists during the anti-Soviet Afghan campaign. This constitutes a motivational framing (in Snow's and Byrd's parlance [2007]) that has greatly influenced generations of militants to take part in campaigns in Bosnia, Chechnya, more recently in Iraq, and once again in Afghanistan (Hegghammer, 2010). Its impact is amplified when combined with both the celebration of heroism by the AGs' propaganda using martyrdom videos and with the radical preaching within the Muslim world justifying violent jihad and suicide missions.

easily influenced by public opinion and group pressure. They also suffer from a feeling of inadequacy, and the demonstrative sacrifice carries the promise of glory and the promise of instantaneously turning a feeling of impotence into a show of power [...]." Additionally, militants having an impulsive-unstable pattern "tend to be impetuous, volatile, and self-destructive. With these characteristics in mind, it easy to comprehend why they volunteer for suicide missions. At the same time, however, they are also unstable and may easily change their minds. This may explain why all would-be suicide bombers in the sample, who evidently tried to activate the explosive charge, belonged to the dependent-avoidant personality rather than to the impulsive-unstable category." Finally, those affected by suicidal tendencies "had an urge to die for personal reasons, unrelated to the ostensible political cause. For these youngsters, 'martyrdom', a socially admired death, was an excellent choice in a society that otherwise condemns self-destruction." (Merari 2010, p.268). 


\subsection{MOTIVATIONS FOR TERRORIST MILITANCY}

Focusing on AFs' action formation mechanisms, a first step is to recognize the contributions of the rational choice theory. In some cases, fighters may rationally conceive of their behavior as an instrumental action (Zweckrational, Weber, 1978 [1922]) with respect to both egoistic and altruistic goals. In suicide missions, for instance, the former might consist of purely personal reasons triggering suicidal tendencies (Merari, 2010). An example is a status crisis caused by a perceived loss of reputation following past misdeeds such as extramarital relationships, and reliance on acts of martyrdom as way to expiate one's deviant behavior (Pedahzur, 2005). In other circumstances, engaging in risky political activities can also be an opportunity for overcoming social marginalization (Khosrokhavar 2005, 2009), gaining social consideration (Ricolfi, 2005; cf. Elster, 2005), and for experiencing solidarity (Wintrobe, 2006; cf. Elster, 2009) and a sense of comradeship (Sageman, 2008). In other cases, instrumental rationality has to do less with self-interest than with altruistic goals ${ }^{17}$. Examples are material benefits for the AFs' intimates such as economic aid for family members provided by AGs. Altruism can also consist of viewing self-sacrifice as the most efficient combat method for the community's goals ${ }^{18}$.

17 As stated by Jon Elster, "[w] hat is 'best' is defined in terms of 'betterness' or preferences: The best is that than which none is better, as judged by the agent. There is no implication that the desires be selfish. The confusion of rationality and egoism is a crude error, although one that is facilitated by the practice of some rational-choice theorists." (Elster, 2007, p. 193; see also Weber 1978 [1922]; Demeulenaere, 2003).

I8 An example is the following statement by a Palestinian woman captured during the Second Intifada: "I wanted to sacrifice myself for Palestine, for our land, and to kill many Jews. You use Apache helicopters, F-I5 aircraft, and tanks against us and you have all the weapons. For us, the only weapon available is people like me, who take explosives and commit suicide. Since I was a baby, all I have seen is war, dead people, hatred and blood. From the beginning of the Intifada I have followed what is happening and I have seen only blood and killing and Palestinian children who are being killed. I told myself that, just as you pay taxes to your country, my tax will be my body. I will give my body for the Palestinian cause." (cited in Kimhi and Even, 2004, p. 828). 
Again, approaches exclusively based on the rational choice theory run the risk of ignoring other motivational factors. Any realistic account of social behavior should first consider emotions (Elster, 2007; Barbalet, 2006; Goodwin et al., 200I; Goodwin et al., 2004; Rice, 2009). For example, militancy might result from such action tendencies as a desire to avenge intimates due to anger following their assassination by occupying forces. Other emotions such as shame and guilt might be intertwined with embracing engagement as a reaction to wrongdoings (Elster, 2007). Radicalization could also be affected by frustrated expectations and deprivation generated by unfavorable socio-economic conditions (Gambetta and Hertog, 2009). Finally, feelings such as loyalty are often behind the drive to protect the community's honor (Goodwin et al., 200I; Hegghammer, 2007). As with ICs, normative beliefs - intended as rational orientations irrespective of the instrumentalist versions of rationality - are also decisive motivational elements (Elster, 2005, 2009; see also Durkheim, 2006 [1897]; Barbagli, 2009). There are witnesses to AFs' references to moral principles having a binding effect on their stances. Examples derived from field research on foreign fighters who take part in the Iraq insurgency show both the duty to wage jihad for the liberation of Muslim countries from oppressors, which complies with the principle of Islamic solidarity (Hegghammer, 2007; Peraino, 2008) ${ }^{19}$, and the search for martyrdom, as the noblest sacrifice on the path of one's god and religion ${ }^{20}$.

19 For example, in a video of May 2006 released by the Mujahideen Shura Council one militant states: "By God, we did not leave Saudi Arabia to escape from reality. On the contrary, we left to stand side-by-side with our brothers in Iraq. And we are full of sadness when we witness our sisters being humiliated. And our brothers in Fallujah are being killed on a daily basis. We came to bring victory for the religion of Allah, and to stand against the infidel occupation of Iraq that spread corruption and tyranny in the land." (NEFA, 2006).

20 According to an Islamist community leader interviewed by S. Mekhennet and M. Moss in Zarqa, Jordan, "most of the young people here in Zarqa are very religious. [...]. And when they see the news and what is going on in the Islamic countries, they themselves feel that they have to go to fight jihad. Today, you don't need anyone to tell the young men that they should go to jihad. They themselves want to be martyrs." (Mekhennet and Moss, 2008). 


\subsection{DYNAMIC OF RADICALIZATION}

Transformational mechanisms responsible for terrorist campaigns are also based on AFs' lines of action towards members of peer groups or comrades, AGs and ICs. Recruitment is generally contingent on interactions involving a plurality of agents (Horgan, 2009). Participation in networks of radicals based on friendship and/or kinship social bonds is a source of pressure on potential AFs (della Porta, 1995; Sageman, 2004). As in cases like the 2005 London bombings, early phases of radicalization include low-risk activities such as attending student associations, sport teams, or religious centers, where ties can be forged and become increasingly intense. This process might be followed by a sharing of extremist views and "out-group hate" - derived, for example, from radical preachers such as Abu Hamza Al-Masri at the Finsbury Park mosque in London - which in turn could be fostered by the strengthening of "in-group love" and mutual loyalty between peers. Apart from face-to-face interactions, radicalization is also facilitated by the Internet. Chat rooms and jihadist forums are becoming complementary and alternative breeding grounds and channels to direct relationships with the AG's elite members (Sageman, 2008; Gunaratna and Oreg, 20ıо; Mussawi, 20ı0).

AFs' attitudes towards the AG's elite generally take on the form of a charismatic legitimacy (Weber, 1978 [1922]). Potential AFs affected by traits such as a dependent-avoidant personality are especially vulnerable to AGs' propaganda and incitement. Psychological patterns like this make them not only more compliant with calls by religious figures, AG commanders and organizers perceived as moral authorities and heroes but also more responsive to ideological narratives from their community members, radical preachers, or mass media exalting violent jihad and martyrdom (Merari, 20ı). However, our hypothesis is that the disposition to volunteer for risky missions - observed for example in the case of Hezbollah, Palestinian organizations, and Iraqi insurgents - hardly results solely from personality. The more that combines with both the emotional, instrumental, and normative orientations previously discussed and with interactions within peer groups, the more probable violent radicalization and terrorist campaigns are. 


\section{CONCLUSION}

This article aimed to outline a general framework for the explanation of terrorist campaigns. We proposed a generative model combining a plurality of agents and social mechanisms, as summarized in Figure 2:

Figure 2: An Ideal-typical generative model of terrorist campaigns

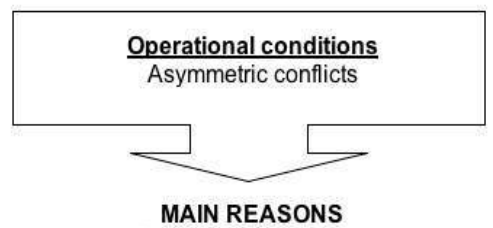

"Technical" and communicative advantages attributed to terrorist tactics

\section{ARMED GROUPS}

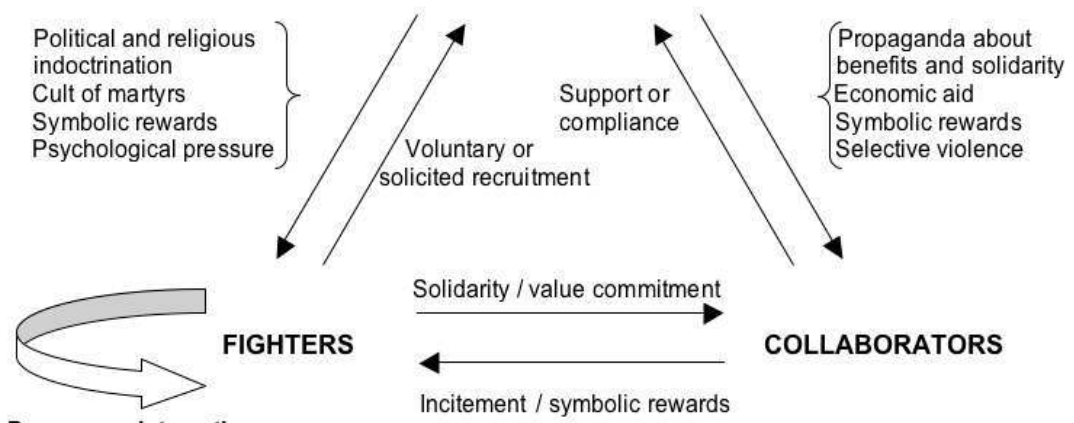

Peer group interactions

\section{MAIN MOTIVATIONS}

Way out of status crises and intimates' needs Search for social consideration

Emotions and feelings such anger and loyalty Political commitment and religious duties

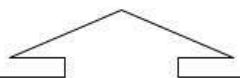

\section{Personal and social conditions}

Suicidal tendencies and personality traits

Personal and community's deprivations

Violence, abuses and humiliation

Political and religious narratives

\section{MAIN MOTIVATIONS}

Source of political and economic benefits Incentives of social capital Emotions such as outrage Political and religious commitment

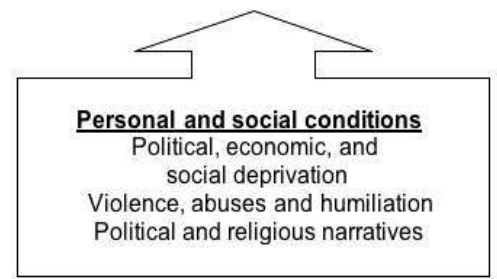


Three main agents were identified. The first are the AGs and their elite members. Our thesis is that their use of terrorist tactics should be traced to instrumental calculations. Violence against civilians is selected here because of its presumed greater efficiency (compared with other combat methods) for operative goals rooted in the situational conditions of asymmetric conflicts. ICs are the second type of agent. We emphasized the necessity of overcoming limitations of accounts based on the rational choice theory - which certainly helps to shed light on instrumental cases of collaboration - to include additional orientations contingent on emotions and norms linked to specific social and cultural conditions. AFs emerged as the third agents. As with ICs, their motivations cannot be reduced to an instrumental rationality, despite its relevance in clarifying some trajectories of militancy. The latter is a more highly complex process that normally combines calculations with emotional and axiological factors, all inevitably intertwined with social background, personality traits, and chains of communal and cultural situations. The model also specifies some of the most important mechanisms which make it possible to describe a terrorist campaign as a collective and macro outcome, that is, interactions between AGs and potential ICs, between AGs and potential AFs, between potential AFs and their community members, including their peer groups.

\section{Acknowledgements}

The author would like to thank Deborah Fraccaro, who on different occasions helped him clarify some of the ideas discussed in this article.

\section{BIBLIOGRAPHY}

ABRAHMS M., forthcoming 2012, "The Political Effectiveness of Terrorism Revisited", Comparative Political Studies, n45/3, [s. p.].

ADAMSKY D., 2010, "Jihadi Operational Art: The Coming Wave of Jihadi Strategic Studies", Studies in Conflict and Terrorism, n³3/ I, p. I-19.

AL-FURGAN, 2009, Knights of Martyrdom (1-5). Retrieved from As-Sahab website. Available at: http://as-sahab.blog.com/2009/0 I/06/al-furqan-presentsknights-ofmartyrdom-all-I-5 (Accessed on: 5 August 2010). 
AL-QASSAM, 2010, Qassam Martyrs - Ezzedeen Al-Qassam Brigades. Retrieved from Al-Qassam website. Available at: http://www.qassam.ps/martyrs.html (Accessed on: 6 August 2010).

AL-ZAWAHIRI A., 200I, "Knights under the Prophet's Banner", in L. Mansfield (ed.), His Own Words: The Writings of Dr. Ayman Al-Zawahiri, Old Tappan, TLG Pub., p. 19-225.

AL-ZAYYAT M., 2004, The Road to Al-Qaeda: The Story of Bin Laden's Right-Hand Man, London, Pluto Press.

AS-SAHAB, 2006, Last Will of the Knights of the Blessed Expedition. Retrieved from As-Sahab website. Available at: http://as-sahab.blog.com/2006/08/07/as-sahabpresentslast-will-of-the-knights-of-the-blessed-expedition-the-london-raidwith-english-subtitles (Accessed on: 7 August 2010).

AYERS N., 2008, "Ghost Martyrs in Iraq: An Assessment of the Applicability of Rationalist Models to Explain Suicide Attacks in Iraq", Studies in Conflict and Terrorism, 31/9, p. 856-882.

BANDURA A., 1998, "Mechanisms of Moral Disengagement", in W. Reich (ed.), Origins of Terrorism, Washington DC, Woodrow Wilson Center Press, p. 161-191.

BARBAGLI M., 2009, Congedarsi dal mondo: il suicidio in Occidente e in Oriente, Bologna, il Mulino.

BARBALET J., 2006, "Emotions in Politics: From the Ballot to Suicide Terrorism", in S. Clarke et al. (eds.), Emotion, Politics and Society, London, Palgrave, p. 3I-55.

BARBERA F., 2004, Meccanismi Sociali, Bologna, II Mulino.

BLOOM M., 2005, Dying to Kill, New York, Columbia University Press.

BOUDON R., 2003, "Beyond Rational Choice Theory", Annual Review of Sociology, n०29, p. I-2I.

-, 2005, "Teoria della scelta razionale o individualismo metodologico: sono la stessa cosa? ", in M. Borlandi and Sciolla (eds.), La Spiegazione sociologica, Bologna, il Mulino, p. 17-32.

-, 2007, Essais sur la théorie générale de la rationalité, Paris, PUF.

-, 2009a, "Rational Choice Theory", in B. S. Turner (ed.), The New Blackwell Companion to Social Theory, Oxford, Blackwell Publishing, p. 179-195. 
-, 2009b, La Rationalité, Paris, PUF.

-, 2010, La Sociologie comme science, Paris, La Découverte.

BOYNS D., BALLARD J.D., 2004, "Developing a Sociological Theory for the Empirical Understanding of Terrorism', American Sociologist, 35/2, p. 5-26.

BRYM R. J., HAMLIN C., 2009, "Suicide Bombers: Beyond Cultural Dopes and Rational Fools" in M. Cherkaoui and P. Hamilton (eds.), Raymond Boudon: A Life in Sociology, Oxford, Bardwell Press, vol. 2, p. 83-96.

CAMPANINI M., MERZAN K., 2007, Arcipelago Islam, Roma-Bari, Laterza.

CASSESE A., 2006 "The multi-faced criminal notion of terrorism in international law", Journal of International Criminal Justice, n4/5, p. 933-958.

CHERKAOUI M., 2005, Invisible Codes: Essays on Generative Mechanisms, Oxford, Bardwell Press.

-, 2007, Good Intentions: Max Weber and the Paradox of Unintended Consequences, Oxford, Bardwell Press.

COLEMAN J., 1990, Foundations of Social Theory, Cambridge (Mass.), Harvard University Press.

COOK D., 2005, Understanding Jihad, Berkeley, University of California Press. -, 2007, Martyrdom in Islam, Cambridge (UK), Cambridge University Press.

CORDESMAN A. H., 2008, Iraq's Insurgency and the Road to Civil Conflict, Westport (Conn.), Praeger.

CRENSHAW M., 1998, "The Logic of Terrorism: Terrorist Behavior as a Product of Strategic Choice", in W. Reich (ed.), Origins of Terrorism, Washington (DC), Woodrow Wilson Center Press, p. 7-24.

CTC, 2007, Al-Qaeda's Foreign Fighters in Iraq, West Point (NY), Combating Terrorism Center. Available at: http://ctc.usma.edu/harmony/pdf/ CTCForeignFighter.19.Dec07.pdf (Accessed on: 15 January 2008). -, 2008, Bombers, Bank Accounts, and Bleedout: Al-Qa'ida's Road in and out of Iraq, West Point (NY): Combating Terrorism Center. Available at: http://ctc.usma. edu/harmony/pdf/Sinjar_2_July_23.pdf (Accessed on: 15 August 2008). 
DELLA PORTA D., 1995, Social Movements, Political Violence and the State: A

Comparative Analysis of Italy and Germany, Cambridge, Cambridge University Press.

DEMEULENAERE P., 2003, Les Normes sociales. Entre accords et désaccords, Paris, PUF.

DENARO, R., 2006, Dal martire allo Šahï. Fonti, Problemi e confronti per una martirografia islamica, Roma, Edizioni di Storia e Letteratura.

DURKHEIM É., 2006 [1897], Suicide, New York, The Free Press.

ELSTER J., 2005, "Motivations and Beliefs in Suicide Missions", in D. Gambetta (ed.), Making Sense of Suicide Missions, Oxford, Oxford University Press, p. 233-258.

-, 2007, Explaining Social Behavior, Cambridge (UK), Cambridge University Press.

-, 2009, Le Désintéressment, Paris, Seuil.

FREAMON B.K., 2003, "Martyrdom. Suicide, and the Islamic Law of War", Fordham International Law Journal, n²7/ I, p. 299-369.

GALBRAITH P.W., 2008, Unintended Consequences: How War in Iraq Strengthened America's Enemies, New York, Simon \& Schuster.

GAMBETTA D., 2005, "Can We Make Sense of Suicide Missions?", in D. Gambetta (ed.), Making Sense of Suicide Missions, Oxford, Oxford University Press, p. 259-299.

-, 2009a, "Signaling", in P. Hedström and P. Bearman (eds.), The Oxford Handbook of Analytical Sociology, Oxford, Oxford University Press, p. I68-194.

-, 2009b, Codes of the Underworld: How Criminals Communicate, Princeton, NJ, Princeton University Press.

- , HERTOG S., 2009, "Way are there so many Engineers among Islamic Radicals?", European Journal of Sociology, n50/2, p. 201-230.

GERGES F. A., 2005, The Far Enemy: Why Jihad Went Global, Cambridge (UK), Cambridge University Press.

GOLBALTERRORALTERT, 2007, "Al-Qaeda's Mujahideen Shura Council - Convoy of Martyrs 2006", Globalterroralert, February. Available at: http://www.globalterroralert.com/video/0207/martyrconvoy0207.wmv (Accessed on: 15 February 2008).

GONZÁLEZ R.J., 2009, "Going 'Tribal': Notes on Pacification in the 2lst Century", Anthropology Today, 25/2, p. 15-19. 
GOODWIN J., 2006, "A Theory of the Categorical Terrorism”, Social Forces, n॰84/4, p. 2027-2046.

- et al. (eds.), 200I, Passionate Politics. Emotions and Social Movements, Chicago, The University of Chicago Press.

- et al., 2004, "Emotional Dimensions of Social Movements",

in D. A. Snow et al. (eds.), The Blackwell Companion to Social Movements, Oxford, Blackwell Publishing, p. 413-432.

GUNARATNA R, OREG A., 2010, "Al-Qaeda's Organizational Structure and Its Evolution", Studies in Conflict and Terrorism, n०33/ 12, p. 1043-1078.

HAFEZ M., 2006, "Martyrdom Mythology in Iraq: How Jihadists Frame Suicide Terrorism in Videos and Biographies", Terrorism and Political Violence, n० 19/1, p. $95-115$.

HAFEZ M., 2007, Suicide Bombers in Iraq, Washington, DC, US Institute of Peace Press. HASHIM A.S., 2006, Insurgency and Counter-Insurgency in Iraq, Ithaca (NY), Cornell University Press.

-, 2009, Iraq's Sunni Insurgency, London, Routledge.

HASSAN R., 2010, Life as a Weapon, London, Routledge.

HEDSTRÖM, P., 2005, Dissecting the Social: On the Principles of Analytical Sociology, Cambridge (UK), Cambridge University Press.

-, SWEDBERG R. (eds.), 1998, Social Mechanisms, Cambridge (UK), Cambridge University Press.

-, YLILOSKI P., 2010, "Causal Mechanisms in the Social Sciences", Annual Review of Sociology, n॰36, p. 49-67.

HEGGHAMMER Th., 2007, "Saudi Militants in Iraq", Norwegian Defence Research Establishment. Available at: http://rapporter.ffi.no/rapporter/2006/03875.pdf (Accessed on: 15 February 2008).

-, 2010, Jihad in Saudi Arabia, Cambridge (UK), Cambridge University Press.

HOFFMAN B., 2006, Inside Terrorism, New York, Columbia University Press.

-, MCCORMICK G.H., 2004, “Terrorism, Signaling, and Suicide Attack”, Studies in Conflict and Terrorism, n²7/4, p. 243-28I. 
HORGAN J., 2009, Walking Away from Terrorism, London, Routledge.

ICG, 2006, "In their own words: Reading the Iraqi insurgency", International Crisis Group, Middle East Report No. 50, February 15: http://www.crisisgroup.org/ home/index.cfm ?id $=3953 \&$ l $=1$.

JACKSON J.W., 2006, Military Intervention in Identity Group Conflicts: A Social Movement Theory Perspective on the Sunni Insurgency in Iraq, Monterey (CA), Naval Postgraduate School.

KALDOR M., 2006, New and Old Wars, Cambridge (UK), Polity Press.

KALYVAS S.N., 2006, The Logic of Violence in Civil War, Cambridge (UK), Cambridge University Press.

KEPEL G., MILELLI J-P. (eds.), 2008, Al-Qaeda in Its Own Words, Cambridge (Mass.), Harvard University Press.

KHOSROKHAVAR F., 2005, Suicide Bombers, London, Pluto Press.

-, 2009, Inside Jihadism, London, Paradigm Publishers.

KIMHI S., EVEN S., 2004, "Who Are Palestinian Suicide Bombers?", Terrorism and Political Violence, n० 16/4, p. 815-840.

KUSHNER H.W., 2003, "Asymmetrical Warfare", in H.W. Kushner, Encyclopedia of Terrorism, London, Sage, p. 54-65.

LAW R. D., 2009, Terrorism: A History, Cambridge (UK), Polity Press.

LEVITT M., 2006, Hamas: Politics, Charity, and Terrorism in the Service of Jihad, Washington, The Washington Institute for Near East Policy.

MANZO G., 2009, La Spirale des inégalités. Choix scolaires en France et en Italie au $x x^{\mathrm{e}}$ siècle, Paris, PUPS.

MANZO G., 20I0, "Analytical Sociology and Its Critics", European Journal of Sociology, n०51/1, p. 129-170.

MEKHENNET S., MOSS M., 2007, "In Jihadist Haven, a Goal: To Kill and Die in Iraq", New York Times, 5 April. 
MEMRI, 2005, "Palestinian Legislative Council Candidate and Bereaved Mother of Three Hamas Terrorists Umm Nidal Farhat", MEMRI TV, 2 I December: http://www.memritv.org/Transcript.asp ?PI $=980$.

MERARI A., 2010, Driven to Death: Psychological and Social Aspects of Suicide Terrorism, Oxford, Oxford University Press.

MOGHADAM A., 2007, "Mayhem, Myths, and Martyrdom: the Shi'a Conception of Jihad", Terrorism and Political Violence, $n^{\circ} 19 / 1$, p. 125-143.

-, 2008, The Globalization of Martyrdom, Baltimore (Md.), John Hopkins University Press.

MÜNKLER H., 2005, The New Wars, Cambridge (UK), Polity.

MUNSON P. J., 2009, Iraq in Transition, Washington DC, Potomac Books.

MUSSAWI M. A., 2010, Cheering for Osama: How jihadists use internet discussion forums. London: Quilliam Foundation. Available at: http://www.quilliamfoundation. org/index.php/component/content/article/700 (Accessed on: 19 October 2010)

NASR V., 2006, The Shia Revival, London, W.W. Norton and Co.

NEFA, 2006, "The Role of Foreign Fighters in the Iraqi Jihad", NEFA Foundation, May. Available at: http://wwwl.nefafoundation.org/multimedia-original.html (Accessed on: 5 March 2008).

OLIVER A.M., STEINBERG P., 2005, The Road to Martyrs' Square, Oxford, Oxford University Press.

PAPE R.A., 2005, Dying to Win, New York, Random House.

-, FELDMAN J.K., 2010, Cutting the Fuse: The Explosion of Global Suicide Terrorism and How to Stop It, Chicago, The University of Chicago Press.

PEDAHZUR A., 2005, Suicide Terrorism, Cambridge (UK), Polity Press.

PERAINO K., 2008, "Destination Martyrdom", Newsweek, 28 April: http://www. newsweek.com/id//32938

POGGI G., 200I, Forms of Power, Cambridge (UK), Polity.

POPITZ H., 1992, Phänomene der Macht, Tübingen, Mohr Siebeck. 
REED D.J., 2008, "Beyond the War on Terror: Into the Fifth Generation War and Conflict", Studies in Conflict and Terrorism, n³1 / 8, p. 664-722.

RICE S.K., 2009, "Emotions and Terrorism Research", Journal of Criminal Justice, $37 / 3$, p. 248-255.

RICOLFI L., 2005, "Palestinians, 198I-2003", in D. Gambetta (ed.), Making Sense of Suicide Missions, Oxford, Oxford University Press, p. 77-130.

RIEDEL B., 2008, The Search for Al-Qaeda, Washington DC, Brookings Institution Press.

SAGEMAN M., 2004, Understanding Terror Networks, Philadelphia, University of Pennsylvania Press.

-, 2008, Leaderless Jihad, Philadelphia, University of Pennsylvania Press.

SCHMID A.P., JONGMAN A.J., 1988, Political Terrorism, London, Transaction Publishers.

SNOW D., BYRD S.G., 2007, "Ideology, Framing Processes, and Islamic Terrorist Movements", Mobilization, no 12/1, p. 119-136.

THORNTON R., 2007, Asymmetric Warfare, Cambridge (UK), Polity Press.

TOSINI D., 2007a, Terrorismo e antiterrorismo nel XXI secolo, Roma-Bari, Laterza.

-, (2007b) "Sociology of Terrorism and Counterterrorism", Sociology Compass, $n^{\circ} 1 / 2$, p.664-68I.

-, 2010, "Al-Qaeda's Strategic Gamble: The Sociology of Suicide Bombings in Iraq", Canadian Journal of Sociology, n’35/2, p. 27I-308.

US ARMY-MARINE CORPS, 2007, Counterinsurgency Field Manual, Chicago and London, The University of Chicago Press.

WEBER M., 1978 [1922], Economy and Society, Berkeley (CA), University of California Press.

WINTROBE R., 2006, Rational Extremism, Cambridge, Cambridge University Press. 